\title{
Sociodemographic profile of blind people: associations with knowledge, attitude and practice about sexually transmitted infections
}

\author{
Perfil sociodemográfico de cegos: associações com conhecimento, atitude e prática sobre \\ infecções sexualmente transmissíveis
}

\section{Perfil sociodemográfico de ciegos: asociaciones con conocimiento, actitud y práctica sobre infecciones de transmisión sexual}

Andressa Kaline Ferreira Araújo ${ }^{1}$, Inacia Sátiro Xavier de França ${ }^{1}$, Alexsandro Silva Coura ${ }^{1}$, Sérgio Ribeiro dos Santos ${ }^{2}$, Ana Paula Andrade Ramos ${ }^{1}$, Lorita Marlena Freitag Pagliuca ${ }^{3}$

Objective: to analyze associations among sociodemographic characteristics and knowledge, attitude and practice of blind people about sexually transmitted infections. Methods: descriptive transversal study with a quantitative approach. Participants were 36 blind individuals. The questionnaire Knowledge, attitude and practice about sexually transmitted infections was used. Absolute and relative frequencies were calculated. There were Chi-square test and chi-square Exact. Results: most participants are elderly, unmarried, with elementary school and not working. Knowledge, attitude and practice about sexually transmitted infections are inadequate $(p<0.05)$. Religion $(p<0.001)$, work $(p<0.001)$, not working reason $(p<0.001)$ and education $(p=0.003)$ had associations with the attitude about sexually transmitted infections. Gender $(\mathrm{p}<0.001)$, marital status $(\mathrm{p}=0.019)$ and education $(\mathrm{p}=0.020)$ had associations with practice. There was no association between sociodemographic characteristics and knowledge. Conclusion: sociodemographic characteristics may interfere with the attitude and practice of blind people about sexually transmitted infections, and the nurse should consider these characteristics in professional practice with those subjects.

Descriptors: Visually Impaired Persons; Sexual Health; Socioeconomic Factors; Public Health.

Objetivo: analisar associações entre características sociodemográficas e conhecimento, atitude e prática de cegos sobre infecções sexualmente transmissíveis. Métodos: estudo descritivo, transversal, com abordagem quantitativa. Participaram 36 indivíduos cegos. Utilizou-se o questionário Conhecimento, atitude e prática sobre infecções sexualmente transmissíveis. Foram calculadas frequências absolutas e relativas. Realizaram-se testes Qui-quadrado e Exato de qui-quadrado. Resultados: a maioria dos participantes é idosa, sem companheiro, cursou ensino fundamental e não trabalha. Conhecimento, atitude e prática sobre infecções sexualmente transmissíveis são inadequados $(\mathrm{p}<0,05)$. Religião $(\mathrm{p}<0,001)$, trabalho $(\mathrm{p}<0,001)$, motivo de não trabalhar $(p<0,001)$ e escolaridade $(p=0,003)$ apresentaram associações com a atitude sobre infecções sexualmente transmissíveis. Sexo $(\mathrm{p}<0,001)$, estado conjugal $(\mathrm{p}=0,019)$ e escolaridade $(\mathrm{p}=0,020)$ apresentaram associações com a prática. Não houve associação entre características sociodemográficas e o conhecimento. Conclusão: as características sociodemográficas podem interferir na atitude e prática de cegos sobre infecções sexualmente transmissíveis, devendo o enfermeiro considerar essas características na práxis profissional com esses sujeitos.

Descritores: Pessoas com Deficiência Visual; Saúde Sexual; Fatores Socioeconômicos; Saúde Pública.

Objetivo: analizar asociaciones entre características sociodemográficas y conocimiento, actitud y práctica de ciegos sobre infecciones de transmisión sexual. Métodos: estudio descriptivo, transversal, cuantitativo. Participaran 36 ciegos. Se utilizó cuestionario de Conocimiento, actitud y práctica sobre infecciones de transmisión sexual, calculadas frecuencias absolutas y relativas, y realizadas pruebas Chi-cuadrado y Exacto de Chi-cuadrado. Resultados: Participantes, en mayoría, eran ancianos, sin parejas, cursaron escuela primaria y no trabajaban. Conocimiento, actitud y práctica sobre infecciones de transmisión sexual son inadecuados $(\mathrm{p}<0,05)$. Religión $(\mathrm{p}<0,001)$, trabajo $(\mathrm{p}<0,001)$, motivo de no trabajar $(\mathrm{p}<0,001)$ y escolaridad $(p=0,003)$ presentaron asociaciones con actitud sobre infecciones sexualmente transmisibles. Sexo ( $p<0,001)$, estado civil $(\mathrm{p}=0,019)$ y escolaridad $(\mathrm{p}=0,020)$ asociaciones con la práctica. No hubo asociación entre características sociodemográficas y conocimiento. Conclusión: características sociodemográficas pueden interferir en la actitud y práctica de ciegos sobre infecciones sexualmente transmisibles, el enfermero debe considerar estas características en la práctica profesional con estos sujetos.

Descriptores: Personas con Daño Visual; Salud Sexual; Factores Socioeconómicos; Salud Pública.

\footnotetext{
${ }^{1}$ Universidade Estadual da Paraíba. Campina Grande, PB, Brazil.

${ }^{2}$ Universidade Federal da Paraíba. João Pessoa, PB, Brazil.

${ }^{3}$ Universidade Federal do Ceará. Fortaleza, CE, Brazil.

Corresponding author: Andressa Kaline Ferreira Araújo

Rua Frederico Trota, 159, apto 1002A, Residencial Green Garden -Alto de São Manoel. CEP: 59631-190 - Mossoró, RN, Brazil. E-mail: andressakfa@hotmail.com
} 


\section{Introduction}

Sexually transmitted infections are one of the most important public health problems in the world ${ }^{(1)}$. Different segments of the population are vulnerable to these infections, like the disabled people, especially the blind individuals, since they live in a context of social exclusion and they face attitudinal barriers that limit their access to comprehensive health care, including actions aimed to sexual and reproductive health $^{(2)}$.

Blindness is also configured as a serious public health problem, since most cases are concentrated in developing countries and are due to preventable causes such as cataracts, glaucoma, corneal infections and measles ${ }^{(3)}$. In the world, there are 285 million people with visual impairments, and from them, 39 million are blind ${ }^{(4)}$. In Brazil, 506,377 people are blind; and of this total, 8,477 cases were reported in Paraíba ${ }^{(5)}$.

Regarding to social rights of these people, it is understood that although there is legislation ensuring sexual education and reproductive health of people with disabilities, there are still gaps in the implementation of actions to ensure these rights for blind people, as well as access to prevention programs of diseases ${ }^{(6)}$.

In this context, it is important to study the knowledge (domain on a particular subject), attitude (perception, feelings and opinions on the thematic) and practice (behavior according to knowledge and attitude people have about the thematic and in response to a stimulus) of blind people about the transmission of infection through sex as determinants of vulnerability to these disorders ${ }^{(7)}$.

By the scarcity of resources for prevention of sexual risks related to blind people and before some gaps in scientific production, the study may help health education interventions to promote sexual health; qualifying communication between health professionals and patients; supporting the construction of low-cost technologies to improve information access and service on sexual health and risk prevention for blind people; providing information to enable the (re) formulation of public policies aimed at full citizenship of people with disabilities; and multidisciplinary health care plan for better autonomy and quality of life and health of blind people, justifying this research.

From this perspective, the objective was to analyze associations among sociodemographic characteristics and knowledge, attitude and practice of blind people about sexually transmitted infections, and raised the following hypothesis: there are associations among variables of sociodemographic and knowledge, attitude and practice of blind people about such infections.

\section{Method}

Descriptive, cross-sectional, quantitative study, conducted in 78 basic family health units of the urban area of the six health districts of the city of Campina Grande/PB, Brazil, between August 2014 and July 2015.

There were 58 blind people identified, of which 36 were included in the non-probabilistic sample, respecting the inclusion criteria: people aged 18 years old or more, both genders, presenting bilateral blindness. Exclusion criteria were: to present multiple disabilities, unable to answer the questionnaire because of illness, be ascribed in micro area discovery and unavailability of Community Health Agents to carry out visits. Considering these criteria, there were 16 blind people excluded from the research. In addition, there were six refusals to participate in the research, ethical precept respected by the researchers.

Previously scheduled visits were held to the basic family health units in order to survey the number of blind people. Later, with the help of community health agents, blind people ascribed were visited to collect data.

The questionnaire Knowledge, attitude and practice about sexually transmitted infections 
was used, instrument proposed by the Ministry of Health (Brazil) and used in the Survey of Knowledge, Attitudes and Practices of the Brazilian population $^{(8)}$; and the following variables were addressed: sociodemographic conditions; knowledge of the ways of prevention and transmission of some sexually transmitted infections; attitude related to the detection of human immunodeficiency virus (HIV) by the test for acquired immunodeficiency syndrome (AIDS); sexual practices related to sexually transmitted infections; and female practice related to the detection of these infections.

Regarding the ways of prevention and transmission, an appropriate knowledge was considered when five assertive questions: they can not be infected by sexually transmitted infections through mosquito; they can not be infected for such infections using public restrooms; they can be infected for AIDS, syphilis and hepatitis by sharing syringe or needle with others; they can be infected for AIDS, syphilis, hepatitis and gonorrhea by not using condoms in sexual intercourse; there is cure for syphilis, hepatitis and gonorrhea, but there is no cure for AIDS. Inadequate knowledge was adopted when there was na error of the five above assertive questions.

As for the detection of HIV, it was considered appropriate attitude towards people who do the ultimate test for AIDS for the following reasons: employer's request, donated blood as needed or wanted, had some risky behavior, partner infected by the AIDS virus, prenatal, curiosity. Inadequate attitude was reflected when the participant(s) had other motivations to do the last test for AIDS than those previously described.

In sexual practices related to sexually transmitted infections, it was considered appropriate practice for the following situations: 1) Women who have never had any of the following problems: secretion, sore vagina, small blisters in the vagina and warts in the vagina; or who have had one of these problems and sought medical and/or pharmacist treatment; and received some of these guidelines: use condoms regularly, inform the partner (s), take an HIV test and/or do the syphilis test. 2) Men who have never had any of the following problems: secretion in urine way, sores on the penis, small blisters on the penis, warts on the penis; or who have had one of these problems and sought medical and/or pharmacist treatment; and received some of these guidelines: use condoms regularly, inform the partner (s), take an HIV test and/or do the syphilis test.

With respect to feminine practice related to the detection of sexually transmitted infections, it was considered adequate when the women underwent gynecological examination in the past three years, and inadequate when they did not undergo for more than three years.

The data collected through the questionnaire were compiled into an electronic database; subsequently processed and analyzed using the statistical program The SAS System 9.0; and presented in tables. To meet the objectives of the study, basic methodologies of exploratory analysis were used as absolute and relative frequencies for variables related to socio-demographic profile and adequacy of knowledge, attitude and practice. In order to verify statistically equal proportions, it was calculated p-value of the variables with the adequacy of knowledge, attitude and practice by chi-square test, with univariate analysis.

Associations of sociodemographic information to the variables of knowledge, attitude and practices were evaluated statistically. For this, the chi-square test for independence was used, with the calculation of the exact p-value, given that the study shows low frequency category.

The project was submitted to the Ethics Committee for Research Involving Human Beings of the State University of Paraíba, under the Protocol 070988/2014. Participants signed the Informed Consent From as instructed by Resolution No. 466/2012 of the National Health Council; and those who could not sign his name, inserted the finger impression of the thumb of his right hand in that form. 


\section{Results}

With regard to demographic data, it is emphasized that most blind people of this study are female (19), elderly (28), does not live with a partner (20), had complete elementary education (25), was not declare as white (21), is Catholic (23) does not work (34) by being retired or being considered unfit for work (22).

Table 1 shows that most of respondents has inadequate concepts for knowledge, attitude and practice about sexually transmitted infections; and all variables, there was statistical difference between the responses considered appropriate and inappropriate in the univariate analysis.

Table 1 - Adequate knowledge, attitude and practice of the study participants

\begin{tabular}{|c|c|c|}
\hline Variable & $\mathbf{n}$ & p-value \\
\hline \multicolumn{3}{|c|}{$\begin{array}{l}\text { Knowledge about prevention and transmission of } \\
\text { some sexually transmitted infections }\end{array}$} \\
\hline Adequate & 1 & $<0.001$ \\
\hline Inadequate & 35 & \\
\hline \multicolumn{3}{|c|}{ Attitude related to HIV detection through Aids test } \\
\hline Adequate & 1 & $<0.001$ \\
\hline Inadequate & 35 & \\
\hline \multicolumn{3}{|c|}{$\begin{array}{l}\text { Sexual practice related to sexually transmitted infec- } \\
\text { tions }\end{array}$} \\
\hline Adequate & 10 & 0.008 \\
\hline Inadequate & 26 & \\
\hline \multicolumn{3}{|c|}{$\begin{array}{l}\text { Female practice related to detection sexually transmit- } \\
\text { ted infections }\end{array}$} \\
\hline Adequate & 4 & 0.013 \\
\hline Inadequate & 14 & \\
\hline Women who did not answer and/or men & 18 & \\
\hline
\end{tabular}

Association between sociodemographic characteristics and knowledge were analyzed statistically described in Table 2 . It is focused that women, elderly people, people who do not live with a partner and those declared as white, all had inadequate knowledge; and statistically significant associations were identified.
Table 2 - Associations of sociodemographic characteristics and knowledge about prevention and transmission of sexually transmitted infections

\begin{tabular}{|c|c|c|c|}
\hline \multirow[t]{2}{*}{ Variable } & \multicolumn{2}{|c|}{$\begin{array}{l}\text { Knowledge about } \\
\text { prevention and } \\
\text { transmission of STI }\end{array}$} & \multirow[b]{2}{*}{ p-value } \\
\hline & $\begin{array}{c}\text { Adequate } \\
\mathbf{n}\end{array}$ & $\begin{array}{c}\text { Inadequate } \\
\mathbf{n}\end{array}$ & \\
\hline \multicolumn{4}{|l|}{ Gender } \\
\hline Female & - & 19 & \multirow[t]{2}{*}{0.2836} \\
\hline Male & 1 & 16 & \\
\hline \multicolumn{4}{|l|}{ Age (years old) } \\
\hline Up to 40 & - & 3 & \multirow[t]{3}{*}{0.1153} \\
\hline 41 to 59 & 1 & 4 & \\
\hline$\geq 60$ & - & 28 & \\
\hline \multicolumn{4}{|l|}{ Marital status } \\
\hline Live with a partner & 1 & 15 & \multirow[t]{2}{*}{0.8638} \\
\hline Do not live with a partner & - & 20 & \\
\hline \multicolumn{4}{|l|}{ Education level } \\
\hline Illiterate & - & 7 & \multirow[t]{4}{*}{0.8735} \\
\hline Complete elementary school & 1 & 24 & \\
\hline Complete high school & - & 2 & \\
\hline Complete higher education & - & 2 & \\
\hline \multicolumn{4}{|l|}{ Race } \\
\hline Yellow & - & 1 & \multirow[t]{4}{*}{0.3536} \\
\hline White & - & 15 & \\
\hline Brown & - & 14 & \\
\hline Black & 1 & 5 & \\
\hline \multicolumn{4}{|l|}{ Religion } \\
\hline Catholic & 1 & 22 & \multirow[t]{4}{*}{0.1261} \\
\hline Evangelic & - & 11 & \\
\hline Umbanda/Candomblé & - & 1 & \\
\hline Without religion & - & 1 & \\
\hline \multicolumn{4}{|l|}{ Work } \\
\hline Not working & 1 & 33 & \multirow[t]{3}{*}{0.9702} \\
\hline Government Employee & - & 1 & \\
\hline Self-employed & - & 1 & \\
\hline \multicolumn{4}{|l|}{ Reason of not working $(n=34)$} \\
\hline Retired/disabled & 1 & 21 & \multirow[t]{3}{*}{0.8838} \\
\hline Disease & - & 3 & \\
\hline Other (missing categorization) & - & 9 & \\
\hline
\end{tabular}

The associations of sociodemographic characteristics with the attitude and practical information, with statistical significance, were presented in Tables 3 and 4. There was no statistical association between sociodemographic variables and knowledge of prevention methods and transmission of some sexually transmitted infections. 
It is highlighted in Table 3, that among Catholics individuals, who do not currently work, retirees and those who have finished elementary school, all have bad attitude.

Table 3 - Associations of sociodemographic characteristics and attitudes related to HIV detection by AIDS test

\begin{tabular}{|c|c|c|c|}
\hline \multirow{3}{*}{ Variable } & \multicolumn{2}{|c|}{$\begin{array}{l}\text { Attitude related to the } \\
\text { detection of HIV }\end{array}$} & \multirow{3}{*}{ p-value } \\
\hline & Adequate & & \\
\hline & $\mathbf{n}$ & $\mathbf{n}$ & \\
\hline \multicolumn{4}{|l|}{ Religion } \\
\hline Catholic & - & 23 & $<0.001$ \\
\hline Other & 1 & 11 & \\
\hline Without religion & - & 1 & \\
\hline \multicolumn{4}{|l|}{ Work } \\
\hline Not working & - & 34 & $<0.001$ \\
\hline Working & 1 & 1 & \\
\hline \multicolumn{4}{|l|}{ Reason of not working $(n=34)$} \\
\hline Retired/ disabled & - & 22 & $<0.001$ \\
\hline Other & - & 12 & \\
\hline \multicolumn{4}{|l|}{ Education level } \\
\hline Illiterate & - & 7 & 0.003 \\
\hline Complete elementary school & - & 25 & \\
\hline Complete high school & - & 2 & \\
\hline Complete higher education & 1 & 1 & \\
\hline
\end{tabular}

Association was found between sexual practices related to sexually transmitted infections and gender ( $p<0.001$ ). In this relationship, $100.0 \%$ of women and $41.0 \%$ of men have had an inadequate sexual practice.

With regard to the female practice related to detection of sexually transmitted infections, most women not living with a partner has bad practice, as well as most illiterate and attended elementary school, as shown in Table 4.
Table 4 - Associations of sociodemographic and female practice related to the detection of sexually transmitted infections

\begin{tabular}{|c|c|c|c|c|}
\hline \multirow{3}{*}{ Variable } & \multicolumn{3}{|c|}{$\begin{array}{l}\text { Female practice related to the } \\
\text { detection of STI }\end{array}$} & \multirow{3}{*}{ p-value } \\
\hline & \multicolumn{3}{|c|}{ Adequate Inadequate other* } & \\
\hline & $\mathbf{n}$ & $\mathbf{n}$ & $\mathbf{n}$ & \\
\hline \multicolumn{5}{|l|}{ Gender } \\
\hline Female & 4 & 14 & 1 & $<0.001$ \\
\hline Male & - & - & 17 & \\
\hline \multicolumn{5}{|l|}{ Marital status } \\
\hline Live with a partner & 2 & 1 & 13 & 0.019 \\
\hline Do not live with a partner & 2 & 13 & 5 & \\
\hline \multicolumn{5}{|l|}{ Education level } \\
\hline Illiterate & - & 5 & 2 & 0.020 \\
\hline Complete elementary school & 2 & 8 & 15 & \\
\hline Complete high school & 2 & - & - & \\
\hline Complete higher education & - & 1 & 1 & \\
\hline
\end{tabular}

\section{Discussion}

In the analysis of demographic data, it was found that gender, race and education are in line with the characteristics of blind people nominated by the Brazilian Institute of Geography and Statistics, 2010 census - 268839 (53.0\%) are women; 266814 (53.0\%) reported being of white race; and 440,548 (87.0\%) are literate. As for literacy, it shows that the index of blind people is lower than the total population ${ }^{(5)}$.

Regarding gender, other research were identified in which the largest number of blind people are women $^{(9)}$, as well as studies in which the most blind were male ${ }^{(3,10-11)}$.

Regarding the race, the number of people who reported being brown or black exceeded that white women, different outcome of the study also carried out with blind people in Campina Grande/Paraíba, Brazil $^{(11)}$.

In this study, most participants do have work 
activities because they are retired or are declared unfit for working. The number of elderly corroborates another study with blind individuals, which states that $81.0 \%$ of women and $69.0 \%$ of men are elderly with bilateral loss of vision ${ }^{(9)}$.

With regard to religion, a research of blind women in Fortaleza/Ceará, Brazil also points out that most people are Catholic ${ }^{(12)}$; in marital status, this study corroborates studies which state that most blind people do not live with a partner ${ }^{(11)}$.

Regarding the knowledge of blind people on the main ways of prevention and transmission of some sexually transmitted infections, it is worrying the fact that most of these individuals have inappropriate domain. This aspect denotes the situation that blind people have access barriers to health education activities on this theme. Published studies also show similar situation, in which people with visual impairments have only superficial information about such infections ${ }^{(13-15)}$. But it was possible to find a research where blind people mentioned general notions domain about prevention and transmission of diseases $^{(16)}$.

It is noteworthy that people with visual disabilities, including blind people do not have access to campaigns by the state, being necessary, therefore, to implement strategies that facilitate access to current and complete content, especially information about infection prevention transmitted during sexual intercourse, sexual and reproductive health; and to allow these people know well the functioning of their body ${ }^{(13,17)}$.

Regarding the attitude related to HIV detection, some participants underwent testing for AIDS, in most cases, motivated by opinions and perceptions deemed inadequate. A study reports that these people do not perform the test due to discrimination in services, because they are considered asexual; to communication barriers and concerns related mainly to confidentiality ${ }^{(18)}$.

With regard to sexual practice related to sexually transmitted infections, most participants in this study were considered with an inappropriate behavior. This can be explained by the lack of information that people have on the subject ${ }^{(17)}$. In another study, participants expressed the need for access to information about the characteristics of these infections so that there is a proper identification from the perception ${ }^{(13)}$. This practice would help with the early detection of cases, probable with a proper treatment and reduction of complications for the health of these people, since sexual dysfunction, infertility, miscarriage, birth of premature babies and death represent the main complications of late diagnosis of sexual transmitted infections $^{(19)}$.

Of the total of blind women in this study, most had never practice the pelvic exam or done it for more than three years ago, characterizing an inappropriate and disturbing practice, the detection of sexually transmitted infections, because women are more prone to these infections, presenting often asymptomatic, which makes difficult the identification of the disease ${ }^{(19)}$.

Thus, the result of this study confirms the susceptibility of blind women to late diagnosis of sexually transmitted infections, which may be also associated with the difficulty of access to health services, whether by structural barriers, by unprepared professionals in attending, effectively, blind people, as evidenced by the threat to the confidentiality of care, or because of professional communication barriers with the patient ${ }^{(16)}$.

Although there have not been identified statistical associations between sociodemographic variables and knowledge of prevention methods and transmission of some sexually transmitted infections, it is believed that social factors such as religion and education level are closely related to a given population on a thematic. It is known that religious standards interfere with perception, feelings and opinions of an individual on a given subject ${ }^{(7)}$; and the theme sexual health is still considered taboo and embarrassment in some religions, aspect responsible for silencing information about it. 
Regarding sociodemographic characteristics statistical associations between and attitudes related to HIV detection, most blind people of this research attended elementary school and presented in its entirety, bad attitude, information that contrasts with research carried out with the Brazilian population, pointing out that most women with complete primary education, conducted HIV test ${ }^{(8)}$.

As regards the statistical associations between sociodemographic characteristics and sexual practice, only the gender variable was statistically significant, highlighting inappropriate behavior of all women; on the national scene, men and women had adequate practice $^{(8)}$.

On female practice related to the detection of sexually transmitted infections, it was perceived misconduct related to the following sociodemographic variables: gender, marital status and educational level. It was observed that all women in this study have inadequate practice; and, most men have appropriate behavior. In a comparative study of gender among people with visual impairments, about sexuality, sexually transmitted infections and condom, it is reported limited knowledge about safe sex practices by blind women and silencing about sexual practices $^{(14)}$. This may be associated with the guidance that women receive about having control over their will and the difficulty in addressing issues related to sexuality ${ }^{(15)}$. Furthermore, it is believed that despite the school representing health oriented environment, it is not determinant to the acquisition of knowledge and change behavior related to the use of condoms ${ }^{(20)}$.

\section{Conclusions}

This study showed that the participants are mostly female, elderly, unmarried, have a low level of education and are not working. They had inadequate concepts about knowledge, attitude and practices on prevention, transmission and detection of sexually transmitted infections.
It was not identified in this study statistical association between sociodemographic variables and knowledge of how to prevent transmission and, contrary to the hypothesis proposed.

These results provide input for planning and implementing health education actions. It is suggested to perform longitudinal studies that assess knowledge, attitudes and practices of blind people about sexually transmitted infections after intervention with accessible educational activities to this population group.

The research presents limits as the amount of participants being low, which limits the power of generalization of the findings.

\section{Collaborations}

Araújo AKF contributed for data collection, analysis and interpretation, article writing and final approval of the version to be published. Ramos APA contributed for data collection, critical review and final approval of the version to be published. França ISX collaborated with analysis and interpretation of data, critical review and final approval of the version to be published. Coura AS, Santos SR and Pagliuca LMF collaborated with critical review of the manuscript and final approval of the version to be published.

\section{References}

1. Reis CB, Bernardes EB. O que acontece atrás das grades: estratégias de prevenção desenvolvidas nas delegacias civis contra HIV/AIDS e outras doenças sexualmente transmissíveis. Ciênc Saúde Coletiva. 2011; 16(7):3331-8.

2. Ministério da Saúde (BR). Secretaria de Atenção à Saúde. Departamento de Ações Programáticas Estratégicas. Política Nacional de Saúde da Pessoa com Deficiência. Brasília: Ministério da Saúde; 2010.

3. Fadamiro CO. Causes of blindness and career choice among pupils in a blind school; South Western Nigeria. Ann Afr Med 2014; 13(1):16-20. 
4. Pascolini D, Mariotti SP. Global estimatives of visual impairment: 2010. Br J Ophthalmol. 2012; 96:614-8.

5. Instituto Brasileiro de Geografia e Estatística (IBGE). Censo Populacional 2010. Rio de Janeiro: IBGE; [Internet]. 2010 [citado 2015 ago 03]. Disponível em: ftp://ftp.ibge.gov.br/Censos/ Censo_Demografico_2010/Caracteristicas_ Gerais_Religiao_Deficiencia/tab1_3.pdf.

6. França DNO. Direitos sexuais, políticas públicas e educação sexual no discurso de pessoas com cegueira. Rev Bioét Impr. 2014; 22(1):126-33.

7. Gummucio S. Data collection: Quantitative methods The KAP survey model (Knowledge, Attitude \& Practices). França: Médecins Du Monde [Internet]; 2011. [cited 2015 ago 03]. Available from: https://www.spring-nutrition. org/publications/tool-summaries/kap-surveymodel-knowledge-attitudes-and-practices.

8. Ministério da Saúde (BR). Secretaria de Vigilância em Saúde. Departamento de DST, Aids e Hepatites Virais. Pesquisa de conhecimento, atitudes e práticas na população brasileira. Brasília: Ministério da Saúde; 2011.

9. Rius A, Artazcoz L, Guisasola L, Benach J. Visual impairment and blindness in Spanish adults. Ophthalmology. 2014; 121(1):408-16.

10. Pagliuca LMF, Cezario KG, Silva EMNR, Melo KM, Lopes MVO. Vaccination coverage of visually impaired adults and sociodemographic characteristics. Rev Rene. 2014; 15(1):22-8.

11. Coura AS, Oliveira CF, França ISX, Enders BC, Dantas DNA, Pagliuca LMF. Associations between leisure activities and pressure and glucose levels of blind adults. Rev Enferm UFPE online [periódico na Internet]. 2013 [cited 2015 ago 03]; 7(1):77987. Available from: http://www.revista.ufpe.br/ revistaenfermagem/index.php/revista/article/ view/3086/pdf_2186

12. Jorge HMF, Bezerra JF, Oriá MOB, Brasil CCP, Araujo MAL, Silva RM. The ways in which blind mothers cope with taking care of their children under 12 years old. Texto Contexto Enferm. 2014; 23(4):1013-21.
13. Barbosa GOL, Wanderley LD, Rebouças CBA, Oliveira PMP, Pagliuca LMF. Development of assistive technology for the visually impaired: use of the male condom. Rev Esc Enferm USP. 2013; 47(5):1163-9.

14. Wanderley LD, Barbosa GOL, Rebouças CBA, Oliveira PMP, Pagliuca LMF. Sexualidade, DST e preservativo: comparativo de gênero entre deficientes visuais. Rev Enferm UERJ. 2012; 20(4):463-9.

15. Bezerra CP, Pagliuca LMF. The experience of sexuality by visually impaired adolescents. Rev Esc Enferm USP. 2010; 44(3):578-83.

16. Saulo B, Walakira E, Darj E. Acess to healthcare for disabled persons. How are blind people reached by HIV services? Sexual Reproductive Healthcare [Internet]. 2012 [cited 2015 ago 03]; 3:49-53. Available from: http://www.ncbi.nlm.nih.gov/ pubmed/22325802

17. Paula AR, Sodelli FG, Faria G, Gil M, Regen M, Meresman S. Pessoas com deficiência: pesquisa sobre sexualidade e vulnerabilidade. Temas Desenvolv. 2010; 17(98):51-65.

18. Nixon AS, Cameron C, Hanasass-Hancock J, Sinwaba P, Solomon PE, Bond VA et al. Perceptions of HIVrelated health services in Zambia for people with disabilities who are HIV- positive. J Int AIDS Soc [Internet]. 2014 [cited 2015 ago 03]; 17(1):18806. Available from: http://www.jiasociety.org/index. php/jias/article/view/18806/3687

19. Theobald VD, Nader SS, Pereira DN, Gerhardt CR, Oliveira FJM. A universidade inserida na comunidade: conhecimentos, atitudes e comportamentos de adolescentes de uma escola pública frente a doenças sexualmente transmissíveis. Rev AMRIGS. 2012; 56(1):26-31.

20. Nicolau AIO, Pinheiro AKB. Sociodemographic and sex determinants of knowledge, attitude and practice of women prisoners regarding the use of condoms. Texto Contexto Enferm. 2012; 21(3):581-90. 